Article

\title{
Simulation Prototyping of an Experimental Solar House
}

\section{Anna Osborne ${ }^{1}$, Stuart Baur ${ }^{1, *}$ and Katie Grantham ${ }^{2}$}

1 Department of Civil, Architectural and Environmental Engineering, Missouri University of Science and Technology, 1401 Pine Street, Rolla, MO 65409, USA; E-Mail: alozzd@ mail.mst.edu

2 Department of Engineering Management, Missouri University of Science and Technology, $600 \mathrm{~W}$. 14th Street, Rolla, MO 65409, USA; E-Mail: kag@mst.edu

* Author to whom correspondence should be addressed; E-Mail: baur@mst.edu; Tel.: +1-573-341-7236; Fax: +1-573-341-4729.

Received: 19 May 2010; in revised form: 2 June 2010 / Accepted: 14 June 2010 / Published: 17 June 2010

\begin{abstract}
This paper presents a comparative analysis between an energy simulation model and an actual solar home. The case study used was the Team Missouri's 2009 Solar Decathlon entry. The home was evaluated using the predicted data developed with the use of Energy-10 Version 1.8. The software simulates the energy use performance of building strategies ranging from building envelope and system efficiency options. The performance data used was collected during the 2009 Solar Decathlon competition. Results comparing energy efficient strategies, consumption and generation are explored with future implications discussed.
\end{abstract}

Keywords: simulation and monitoring; energy analysis; solar decathlon; simulation-based control

\section{Introduction}

The use of energy simulation software has increased significantly in the past ten years as consumers, engineers, and architects become more interested in applying energy conservation and efficiency techniques [1]. With the advances in energy simulation programs numerous research studies have been looking at ways to better predict building energy performance through the use of computer generated models [2-5]. Many different software packages exist such as Energy-10, EnergyPlus and Ecotect to perform this task, several of which have been developed within the Department of Energy [6]. 
These simulations often target "energy retrofits", focusing on decreasing or offsetting the overall energy use of a building by implementing more efficient equipment, improving the building envelope, and optimizing operating conditions.

There is a biennial competition that challenges colleges and universities from around the world to create energy-efficient residential homes. The U.S. Department of Energy Solar Decathlon joins 20 international, collegiate teams in a competition to design, build, and operate the most attractive and energy-efficient solar-powered house [7]. This competition includes both objective and subjective contests. Students from Missouri University of Science and Technology (Missouri S\&T) have participated in this prestigious competition since its conception, producing homes that have ranked well overall. However, there has been little comparison between the solar houses predicted performance and competition performance in order to improve future designs.

\section{Scope of Work}

Having recently competed in the 2009 Solar Decathlon Competition, the solar house team at Missouri S\&T decided to use the information gathered by the U.S. Department of Energy during the scoring and monitoring of the house to create an energy model. This model was begun after the completion of the competition using the Energy-10 software program which was chosen due to its user-friendly interface. The intention of this simulation was to model the home as it was tested during competition, and to use the resulting charts and graphs to conclude if an energy model could be used in the future to predict the performance of the house prior to competition.

Energy-10 Version 1.8 software by the National Renewable Energy Laboratory was used to simulate Team Missouri's 2009 entry into the U.S. Department of Energy's Solar Decathlon. An initial simulation was performed prior to the competition using Energy-10 Version 1.7 for design purposes; however, a revised more accurate simulation was performed after the competition using Version 1.8, allowing data collected during the competition to be used in the analysis.

\section{House Description}

Team Missouri's 2009 Solar Decathlon entry (Figure 1) featured an $8 \mathrm{~kW}$ photovoltaic (PV) array with a solar thermal array composed of evacuated tubes. The south side of the home utilizes a stationary louver system for passive heating and cooling. The structure is composed of Structurally Insulated Panels (SIPS) and utilizes a reversible heat pump as well as radiant floor heating. A home energy monitoring system, 'Chameleon', was developed to monitor the homes environment and energy usage. Accessible via touch screens located throughout the house, users are able to control the LED lighting, operable clerestory windows and shades. The chameleon system monitors weather conditions and runs the appliances at the time when operation will be most energy efficient. 
Figure 1. Team Missouri's 2009 Solar Decathlon entry.

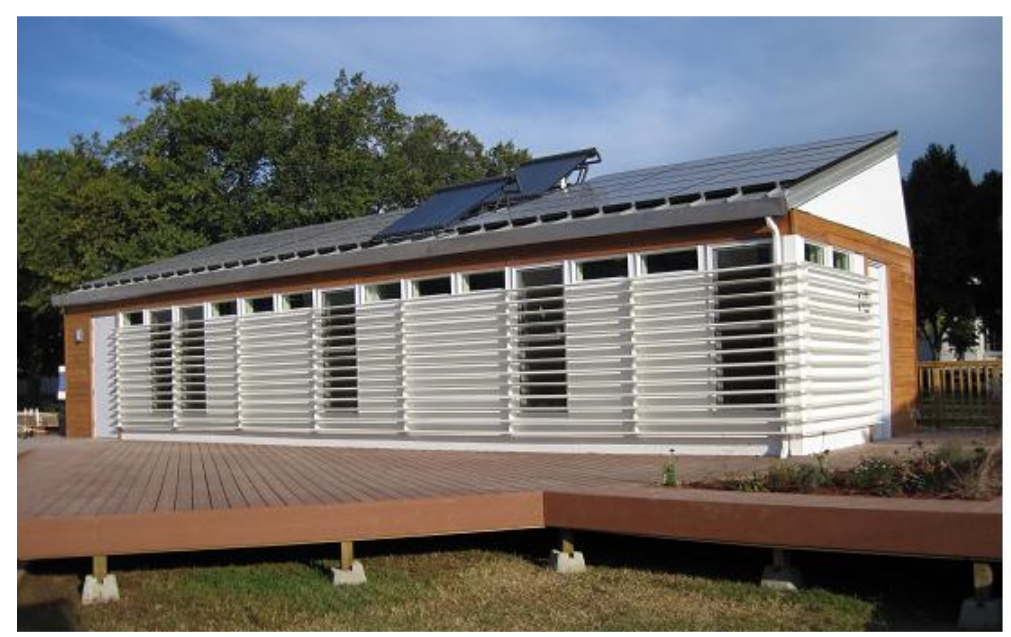

\section{Brief Overview of the 2009 Solar Decathlon Competition}

The 2009 Solar Decathlon Competition took place on the National Mall in Washington D.C. from 8-21 October 2009. The competition allows the teams two years to design and construct their homes. Due to the location, the homes did not only need to be efficient and attractive, they had to be transportable. Therefore, teams were given 7 days to reconstruct their house, test their systems, and tie to the grid. Once constructed, there were 8 days of competition and public tours. During this time, each of the 20 teams had to showcase and test their all electric, solar powered homes. This included jury tours, cooking dinner, doing laundry, and maintaining indoor temperature. The objective contests were the only ones that were taken into consideration during the energy analysis of the home and will be the only ones described in this section. A detailed breakdown of all contests can be found at the Solar Decathlon website [7]. Daily measurements for the 5 objective contests were taken from 8-16 October The 5 objective contests included: Comfort Zone, Hot Water, Appliances, Home Entertainment, and Net Metering. A breakdown of the requirements of these contests is as follows:

- Comfort Zone:

○ $22{ }^{\circ} \mathrm{C}\left(72{ }^{\circ} \mathrm{F}\right) \leq$ Temperature $\leq 24{ }^{\circ} \mathrm{C}\left(76^{\circ} \mathrm{F}\right)$

○ $40 \% \leq$ Relative Humidity $\leq 60 \%$

- Appliances:

○ $1.11{ }^{\circ} \mathrm{C}\left(34{ }^{\circ} \mathrm{F}\right) \leq$ Refrigerator Temperature $\leq 4.44{ }^{\circ} \mathrm{C}\left(40{ }^{\circ} \mathrm{F}\right)$

○ $\quad-29{ }^{\circ} \mathrm{C}\left(-20^{\circ} \mathrm{F}\right) \leq$ Freezer Temperature $\leq-15^{\circ} \mathrm{C}\left(-5^{\circ} \mathrm{F}\right)$

- Clothes Washer: run one complete, uninterrupted cycle within a specified period of time with the temperature reaching at least $43.3^{\circ} \mathrm{C}\left(110^{\circ} \mathrm{F}\right)$ at one point during the cycle

- Clothes Dryer: return a load of laundry to equal to or less than the total weight of the load before washing

- Dishwasher: run a complete, uninterrupted cycle within a specified period of time with the temperature reaching at least $48.9^{\circ} \mathrm{C}\left(120^{\circ} \mathrm{F}\right)$ at one point during the cycle. 
- Home Entertainment:

○ Cooking: use a kitchen appliance to vaporize $2.268 \mathrm{~kg}(5 \mathrm{lb})$ of water within a specified amount of time.

○ Lighting:

- Workstation: keep the workstation desk surface light level above 538 lux (50 foot-candles) during the scoring period

- House: keep all interior and exterior lights on during specified periods of time

- Dining: host two dinner parties for neighbors during contest week

- Public Exhibit: have computer, TV, and home automation displays on during public and jury tours

○ Home Theater: host one movie night for neighbors during contest week

- Hot Water:

○ $56.8 \mathrm{~L}$ (15 gal) of hot water must be drawn in no more than 10 minutes and must reach a minimum temperature of $43.3^{\circ} \mathrm{C}\left(110^{\circ} \mathrm{F}\right)$

- Net Metering:

- produce a net amount of AC electrical energy of $0.0 \mathrm{kWh}$ or more

Portions of the contests, affecting the scoring of the teams and the results of the competition, but not affecting the energy simulation were not described. These 5 contests were intended to simulate the use of the house as if it were being lived in, and most of the contests occurred once daily throughout the 8 days.

\section{Simulation}

Energy-10 is a software tool that, when used in the design phase, can help architects, engineers, and builders quickly identify the most cost-effective and energy-saving measures to implement when designing a low-energy building [8]. More than a dozen sustainable design strategies can be chosen from to find the best fit for a particular location or situation such as passive solar, photovoltaics, and high efficiency HVAC [6].

Initially, several factors such as building size, materials, construction methods and location were used to generate the base model. Next, more detailed information about the structure was incorporated, such as the number, size, and thermal properties of windows, doors, walls, the floor, and the roof [7]. In order to achieve this, the density, specific heat, and thermal conductivity of several materials had to be added to the material database. This included oriented strand board (OSB), polyurethane foam, and Warmboard Radiant Flooring [9].

Specific information regarding system components were updated to the simulation as well. These included the BP Solar SX3200 photovoltaic (PV) panels, the Fronius inverter, and the Apricus evacuated tubes as provided by the manufacturers [11-14].One Energy-10 input that was found to affect the results of the simulation significantly is the Internal Gains dialog box. This tab requires inputting the entire load for all internal lights, external lights, people (in number), hot water, and other. The "Other" category covers all loads that are not included in the aforementioned categories, such as HVAC loads, appliances, and other plug loads. The values in each category are not simulated 
individually; they are simulated as a total load. All of the internal and external lights in the house were LED with the exception of one fluorescent fixture. Therefore, the major loads in the home came from the "Hot Water" and "Other" categories. The appliances and equipment that fall under this category and are relevant to the performance of the house during competition are summarized in Table 1.

Table 1. The various appliances and wattages used in Team Missouri's solar house entry during 2009 Solar Decathlon.

\begin{tabular}{ll}
\hline Hot Water & \\
\hline Appliance & Power (W) \\
Water Heater [15] & 10450 \\
Water Heater (Radiant) [16] & 0 \\
Dishwasher [17] & 1510 \\
TOTAL & 11960 \\
Watts per sq. m. & 200.3 \\
(Watts per sq. ft.) & $(18.60)$ \\
\hline OTHER & \\
\hline Appliance & Power (W) \\
Washer [18] & 330 \\
Dryer [19] & 5760 \\
Refrigerator [20] & 52 \\
Oven [21] & 2900 \\
Cooktop [22] & 2960 \\
Air Heat Pump [23] & 1320 \\
\hline TOTAL & 13322 \\
Watts per sq. m & 223.2 \\
(Watts per sq. ft.) & $(20.72)$ \\
\hline
\end{tabular}

The wattages of the equipment and appliances are summarized in Table 1. These values are taken from the loads provided by the manufacturers. Some of the peak manufacturer loads were reduced based on the actual usage of these elements during competition, as well as to Energy Star Energy Guides for the refrigerator, dishwasher, and washer. For example, the domestic water heater was reduced by $5 \%$ because during competition it was never operated at peak load. The radiant water heater was reduced to zero because the system was not sufficient at keeping the interior temperature consistent and was turned off within the first two days. The heating for the house was then controlled by the air heat pump. The oven and cooktop loads were reduced based on the cooking portion of the competition (i.e. the cooktop was reduced to the equivalent load of the 2 largest burners which would have been the maximum usage during that time).

After all of these values were found and accounted for, the total wattage was divided by the finished floor space of the house, 59.7 sq. m (643 sq. ft.) to give watts per square meter. These values were then placed in the Internal Gains tab, and the hourly profiles of each category were calculated. These hourly profiles, shown in Table 2, were approximated based on the operation schedule of the house during competition. An explanation of what loads were in use during these hours is shown in Table 3. 
Table 2. Load profile for internal gains for weekend.

\begin{tabular}{|c|c|c|c|c|c|c|c|c|c|c|c|c|c|c|c|c|c|c|c|c|c|c|c|c|}
\hline Load & 1 & & & & & 6 & & & & & & 12 & & & & & & 18 & & & & & & $\overline{24}$ \\
\hline Internal Lights & 0 & 0 & 0 & 0 & 0 & 0 & 0 & 1 & 1 & 1 & 3 & 3 & 3 & 3 & 3 & 0 & 0 & 0 & $\mathrm{P}$ & $\mathrm{P}$ & $\mathrm{P}$ & 0 & 0 & 0 \\
\hline External Lights & 0 & 0 & 0 & 0 & 0 & 0 & 0 & 0 & 0 & 0 & 0 & 0 & 0 & 0 & 0 & 0 & 0 & 0 & $\mathrm{P}$ & $\mathrm{P}$ & $\mathrm{P}$ & 0 & 0 & 0 \\
\hline People & 0 & 0 & 0 & 0 & 0 & 0 & 2 & 2 & 6 & 0 & 0 & 0 & 0 & 0 & 0 & 0 & 6 & 6 & 6 & 6 & 6 & 0 & 0 & 0 \\
\hline Hot Water & 0 & 0 & 0 & 0 & 0 & 0 & 0 & 0 & 1 & 0 & 0 & 0 & 0 & 0 & 0 & 0 & 1 & 0 & 1 & 0 & 0 & 0 & 0 & 0 \\
\hline Other & 1 & 1 & 1 & 1 & 1 & 1 & 1 & 1 & 1 & 0 & 0 & 0 & 0 & 0 & 0 & 0 & 4 & 8 & 3 & 1 & 1 & 1 & 1 & 1 \\
\hline
\end{tabular}

Table 3. Load profile calculations for weekend.

\begin{tabular}{|c|c|c|}
\hline Load Type & Load Details & $\begin{array}{c}\text { Relative } \\
\text { Value }\end{array}$ \\
\hline \multicolumn{3}{|l|}{ Internal Lights } \\
\hline 8:00 am-10:00 am & Task Lighting contest & 1 \\
\hline 10:00 am-5:00 pm & Tour lighting & 3 \\
\hline 5:00 pm-7:00 pm & No light usage & 0 \\
\hline 7:00 pm-10:00 pm & All lights on full & $\mathrm{P}$ \\
\hline 10:00 pm-8:00 am & No light usage & $\mathrm{P}$ \\
\hline \multicolumn{3}{|l|}{ External Lights } \\
\hline 7:00 pm-10:00 pm & All lights on full & $\mathrm{P}$ \\
\hline $10: 00 \mathrm{pm}-7: 00 \mathrm{pm}$ & No light usage & 0 \\
\hline \multicolumn{3}{|l|}{ People } \\
\hline 7:00 am-9:00 am & Observer and Project Manager & 2 \\
\hline 9:00 am-10:00 am & Team & 6 \\
\hline 10:00 am-5:00 pm & Tours- no contests & 0 \\
\hline 5:00 pm-10:00 pm & Team & 6 \\
\hline 10:00 pm-7:00 am & No People & 0 \\
\hline \multicolumn{3}{|l|}{ Hot Water } \\
\hline 9:00 am-10:00 am & Hot Water Draw & 1 \\
\hline 10:00 am-5:00 pm & Tours- no hot water usage & 0 \\
\hline 5:00 pm-6:00 pm & Dishwasher & 1 \\
\hline $6: 00 \mathrm{pm}-7: 00 \mathrm{pm}$ & No hot water usage & 0 \\
\hline 7:00 pm-8:00 pm & Hot Water Draw & 1 \\
\hline 8:00 pm-9:00 am & No hot water usage & 0 \\
\hline \multicolumn{3}{|l|}{ Other } \\
\hline 7:00 am-10:00 am & $\begin{array}{l}\text { Air Heat Pump, Refrigerator, and } \\
\text { Cooktop (cooking contest) }\end{array}$ & 1 \\
\hline 10:00 am-5:00 pm & $\begin{array}{l}\text { Tours- TV, Refrigerator, Computer, } \\
\text { Touchscreens }\end{array}$ & 0 \\
\hline 5:00 pm-6:00 pm & $\begin{array}{l}\text { Cooktop, Washer, Air Heat Pump, } \\
\text { Refrigerator }\end{array}$ & 4 \\
\hline $6: 00 \mathrm{pm}-7: 00 \mathrm{pm}$ & $\begin{array}{l}\text { Oven, Dryer, Air Heat Pump, } \\
\text { Refrigerator }\end{array}$ & 8 \\
\hline 7:00 pm-8:00 pm & $\begin{array}{l}\text { Oven and Cooktop (warming only-50\%), } \\
\text { Air Heat Pump, Refrigerator }\end{array}$ & 3 \\
\hline 8:00 pm-7:00 am & Air Heat Pump and Refrigerator & 1 \\
\hline
\end{tabular}


The values inputted in Table 2, from 1-9 with $\mathrm{P}$ being the Peak value, as stated before, were calculated based on what loads were occurring in the house, and what contests were being measured. No contests, with the exception of the internal lights and small loads such as the TV, computer and touchscreens, were measured during tour hours and therefore values during tours are most always zero. For example, he hot water draw contest required the team to draw $56.8 \mathrm{~L}$ (15 gal) of water from a $408.8 \mathrm{~L}$ (108 gal) tank. Therefore the number was calculated as follows based on the numbers from Table 1:

$$
\begin{aligned}
& \text { Relative Value } \rightarrow \frac{1}{10}=\frac{1463 \mathrm{~W}}{11960 \mathrm{~W}}=0.1 \\
& \text { Hot Water Draw }=10450 \mathrm{~W} \frac{15 \mathrm{gal}(56.8 \mathrm{~L})}{108 \mathrm{gal}(408.8 \mathrm{~L})}=1463 \mathrm{~W}
\end{aligned}
$$

Therefore "1" was inputted as the relative value for the hour during which the hot water draw occurred. Similar calculations were preformed based on the information presented in Table 1 and Table 3. A summary of all of the loads can be seen in Figure 2.

Figure 2. Summary of loads for Team Missouri’s 2009 solar house.

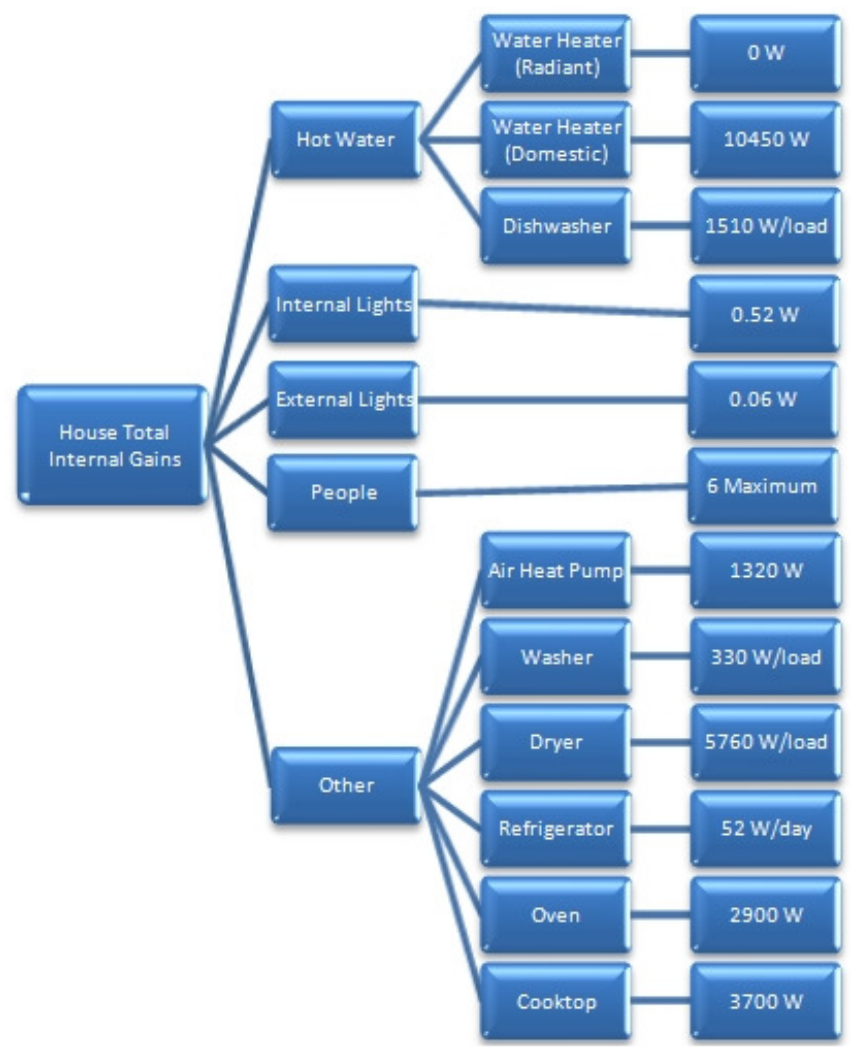

\section{Results and Discussion}

The graph produced from the 2009 Solar Decathlon competition that was used in this comparison can be seen plotted with the Energy-10 graph in Figure 3. In this graph, a positive value indicates PV production, and a negative value indicates building energy consumption. Energy-10 creates many different graphs after a building is simulated. The only graph which allowed a direct comparison to the competition graphs was the hourly Building Electric graph. This is plotted in Figure 3 with the competition graph. It should be noted the Solar Decathlon graph had data points every 15 min while 
the Energy-10 graph took data points every hour, so the Solar Decathlon data was reduced by using only the data collected on the hour.

An important part in the comparison of the data collected during competition and Energy-10 was that the house was grid-tied. Energy-10 automatically simulates PV as a grid-tied system, thus allowing a comparative analysis between the two graphs. As it can be seen in the graph, many of the same trends are followed and PV production can easily be identified during mid day. As detailed in the contest description, cooking a full meal for 6 guests was done in the house on Friday, 9 October, and Monday 12 October. These positive spikes can easily be seen in the graph, on the "SD 09" line. These same positive spikes can be seen in the Energy-10 graph, due to the limits of Energy-10, are shown on the weekends only.

Figure 3. Comparison of $\mathrm{AC}$ power usage and generated between the simulated model vs. measurements.

Simulated vs. Measured Net Power

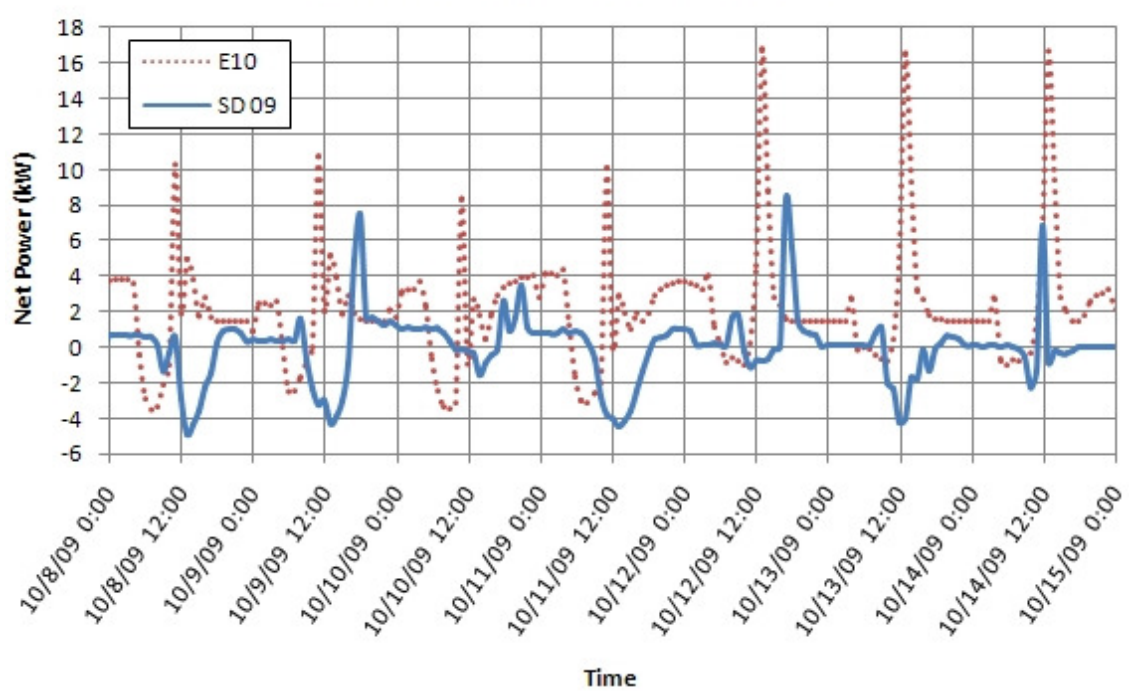

Differences in the graphs could partially be contributed to Energy-10 limiting the user to specify different load profiles for weekdays and weekends. Therefore, the exact operating schedule that the house was tested with in competition was not able to be mirrored in the simulation. Other factors, such as the actual insulation value of the house and windows could have affected the competition results. As was mentioned in the introduction, the houses must be transported, reconstructed, and then deconstructed. Therefore, the house still could have some air leaks due to improperly insulated seams. This error could be eliminated when the home is set up permanently. Other errors could have occurred during construction which could affect the home's performance. The Energy-10 results indicate that much more power was used in the house than actually was for competition purposes. There is a difference of about $10 \mathrm{~kW}$ between the peaks on Wednesday, but only a difference of about $3 \mathrm{~kW}$ between the peaks on Friday night. These differences could be a result of additional factors. The model only allows an hourly profile. Most contests that were simulated did not take an entire hour, such as running the dishwasher, cooking water, hot water draws, and washing clothes. This error could be accounted for in the future by considering the amount of time each contest took, and adjusting the relative value accordingly. 
Other differences that could not be accounted for in the model were based on strategies the team took during competition. For example, the team made a decision to stay net zero for the Energy Balance competition. As a result, Team Missouri opted out of participating in several contests. Therefore, it can be seen that the graph flattens out at the end, on Wednesday, 15 October. Table 4 shows the average net power consumed by the house as measured in competition, and simulated by Energy-10. It is reiterated in this chart that Energy-10 simulates a much higher kilowatt usage. However, it is interesting to note that the kilowatt PV production is often lower than the actual. These differences are inherit with any simulation program and include the use of historical weather data versus actual weather conditions, and the difference in occupant load at any given time causing the effects of latent and sensible heat to be difficult to determine.

Table 4. Average daily net power.

\begin{tabular}{cccc}
\hline & SD09 & E10 & Difference (\%) \\
\hline $10 / 8 / 2009$ & -0.46 & 1.82 & 125.27 \\
$10 / 9 / 2009$ & 0.15 & 1.89 & 92.14 \\
$10 / 10 / 2009$ & 0.69 & 1.92 & 63.77 \\
$10 / 11 / 2009$ & -0.69 & 2.19 & 131.59 \\
$10 / 12 / 2009$ & 0.87 & 2.67 & 67.55 \\
$10 / 13 / 2009$ & -0.51 & 1.94 & 126.43 \\
$10 / 14 / 2009$ & 0.06 & 1.98 & 97.09 \\
$10 / 15 / 2009$ & -0.05 & 1.84 & 102.86 \\
\hline Total & 0.05 & 16.26 & 99.68 \\
\hline
\end{tabular}

\section{Conclusions}

The purpose of this study was to develop an understanding of the various factors that need to be considered in the development of an energy model. The information gained from this study will assist in future solar house designs to consider the additional factors when developing an energy model and improve forecasted projections in terms of energy usage. By isolating certain loads within a model in Energy-10 it can be determined what factors cause a home to use more energy, and different ways to reduce these loads can be researched and implemented.

It is expected that the simulation will not exactly mirror the minute-by-minute numbers accumulated in competition. However, the large discrepancies observed do raise a question as to the accuracy of the simulation. A simulation which enables partial hour load profiles, or minute-by-minute, as well as individual profiles for each load, would allow the user to isolate errors and causes of such discrepancies. From the results of the simulation, it can be concluded that Energy-10 may not be the ideal tool when a highly detailed simulation is required. The purpose of the program is to provide an initial analysis of the chosen systems and structure of the house, and to propose a building using more energy efficient alternatives. This is not the manner in which it was used in this simulation. The team will continue to research other possibilities in building energy modeling, as well as possible improvements to Energy-10 modeling based on errors discovered in the current 2009 model, including modeling partial hours. However, a program which has a wider range of capabilities should be used for a final meticulous analysis. 
Due to its ease of use, Energy-10 is useful in the initial design stages to gauge the effectiveness of chosen systems and allows the user to identify areas of improvement. It is also a reliable source to test different energy efficient strategies and compare the results to find what combinations of strategies lend the most efficient building. These strategies, which range from photovoltaics to passive solar and high efficiency HVAC, can be chosen in any combination to fit the designers' needs. Energy-10 is a valuable source in the beginning stages of energy efficient and sustainable design.

\section{Future Work}

Other building energy modeling resources are being researched by the Missouri S\&T solar house team including EnergyPlus and VE-Ware. VE-Ware has more input possibilities and is compatible with Revit, the required modeling software for the Solar Decathlon, which eliminates time waste associated with duplicate modeling. EnergyPlus not only allows a detailed load profile input, it has a wider range of capabilities and virtually no constraints on input possibilities.

Work will continue on refinement of this energy model including modeling of partial hours in attempt to produce more acceptable results and formulate a strategy for future models. This research project will serve as a reference for the expected performance of the 2009 solar house as an addition to Missouri University of Science and Technology's Solar Building Benchmark. This project already includes Missouri S\&T's 2002, 2005, and 2007 entries into the Solar Decathlon. The Solar Building Benchmark will use a variety of sensors to track energy consumption and record weather conditions, and use this collected data for energy modeling software analysis.

\section{Acknowledgements}

All authors are grateful to Norm Weaver from the Sustainable Buildings Industry Council for providing technical support for Energy-10 as well as members of Team Missouri from the 2009 Solar Decathlon competition who helped with gathering all the required information about the house and its systems: Benjamin Brannon, Lucas Sudkamp, and Cory Brennan. This work has been supported by the U.S. Department of Energy throughout the Solar Decathlon.

\section{References and Notes}

1. Ahmad, M.; Culp, C.H. Uncalibrated building energy simulation modeling results. HVAC \& R Research, 1 October 2006. Available online: http://www.accessmylibrary.com/article-1G1156720225/uncalibrated-building-energy-simulation.html (Accessed on 3 June 2010).

2. Building Energy Software Tools Directory: Tools Listed Alphabetically. Energy Efficiency and Renewable Energy (EERE), U.S. Department of Energy (DOE) Home Page, 6 May 2010. Available online: http://apps1.eere.energy.gov/buildings/tools_directory/alpha_list.cfm (Accessed on 3 June 2010).

3. Crawleya, D.B.; Handb, J.W.; Kummert, M.; Griffith, B.T. Contrasting the capabilities of building energy performance simulation programs. Build. Environ. 2008, 43, 661-673. 
4. Choudhary, R.; Augenbroe, G.; Gentry, R.; Hu, H. Simulation enhanced prototyping of an experimental solar house. Build. Simul. 2008, 1, 336-355. Available online: http://www.springer link.com/content/4847463861788g35/ (Accessed on 14 June 2010).

5. Wang, N.; Esram, T.; Martinez, L.A.; McCulley, M.T. A marketable all-electric solar house: A report of a Solar Decathlon project. Renewable Energy 2009, 34 2860-2871.

6. Solar Decathlon. U.S. Department of Energy, 2009. Available online: http://www.solar decathlon.org/ (Accessed on 3 June 2010).

7. Energy-10. National Renewable Energy Laboratory, 16 December, 2009. Available online: http://www.nrel.gov/buildings/energy10.html (Accessed on 3 June 2010).

8. Small Commercial Buildings Program. Sustainable Buildings Industry Council, 10 March 2010. Available online: http://www.sbicouncil.org/displaycommon.cfm?an=1\&subarticlenbr=8 (Accessed on 3 June 2010).

9. Thermocore, Structural Insulated Panel Systems, 2000. Available online: http://www.thermocoremo.com/images/INSTALL_MANUAL.pdf (Accessed on 3 June 2010).

10. Quaker Windows \& Doors. Brighton ${ }^{\mathrm{TM}}$ Series. Available online: http://www.quakerwindows. com/CD31/Britpw.pdf (Accessed on 3 June 2010).

11. High-efficiency photovoltaic module using silicon nitride multicrystalline silicon cells. BP Solar, 6802.0049-v2. May 2008; Available online: http://www.bp.com/liveassets/bp_internet/solar/ bp_solar_usa/STAGING/local_assets/datasheet_3200W_final.pdf (Accessed on 3 June 2010).

12. Evacuated Tubes. Apricus Solar Co., Ltd., 2008. Available online: http://www.apricus.com/html/ evacuated_tubes.htm (Accessed on 10 February 2010).

13. Apricus Solar Co., Ltd. Document AS-1.2.5.1, August 2006. Available online: http://www.mysolarworld.net/apricusbrochure1.pdf (Accessed on 3 June 2010).

14. Certified Solar Collector. Solar Rating Certification Corporation, June 2010. Available online: http://securedb.fsec.ucf.edu/srcc/coll_detail?srcc_id=2007033A (Accessed on 3 June 2010).

15. Tankless-Water-Heater by Seisco. Tankless Order Page, 4 March 2010. Available online: http://www.seisco.com/orderpage.html (Accessed on 3 June 2010).

16. Seisco SH-22 Micro-Boiler. Radiant \& More, 3 March 2010. Available online: http://www.radiantandmore.com/seisco-sh22-microboiler.html (Accessed on 3 June 2010).

17. Energy Star Energy Guide. KitchenAid, 1 March 2010. Available online: http://www.kitchenaid. com/assets/pdfs/product/ZENERGY/KUDC20CVSS_Energy\%20Guide_EN.pdf (Accessed on 3 June 2010).

18. Energy Star Energy Guide. Whirlpool, 4 March 2010. Available online: http://www.whirlpool. com/assets/pdfs/product/ZENERGY/WFW9550WL_Energy\%20Guide_EN.pdf (Accessed on 3 June 2010).

19. Electric Dryers WED9550WL from Whirlpool Home Appliances. Whirlpool Appliances, 3 March 2010. Available online: http://www.whirlpool.com/catalog/product.jsp?parentCategoryId=113\& categoryId=119\&subCategoryId=121\&productId=1784\&view=1\#tabs (Accessed on 3 June 2010).

20. Energy Star Energy Guide. KitchenAid, 4 March 2010. Available online: http://www.kitchen aid.com/assets/pdfs/product/ZENERGY/KBRC36FTS_Energy\%20Guide_EN.pdf (Accessed on 3 June 2010) 
21. Combination Oven. KitchenAid, 4 March 2010. Available online: http://www.kitchenaid.com/ flash.cmd?/\#/product/KEMS308SSS/ (Accessed on 3 June 2010).

22. Induction Cooktop. KitchenAid, 4 March 2010. Available online: http://www.kitchenaid.com/ flash.cmd?/\#/product/KICU508SBL (Accessed on 3 June 2010).

23. XL20i Heat Pumps, Ultra Efficiency Units-Heat Pump \& Heater: Trane Residential. Trane, 4 February 2010. Available online: http://www.trane.com/residential/products/heatpumps/XL20i-Heat-Pumps (Accessed on 3 June 2010).

(C) 2010 by the authors; licensee MDPI, Basel, Switzerland. This article is an Open Access article distributed under the terms and conditions of the Creative Commons Attribution license (http://creativecommons.org/licenses/by/3.0/). 